\title{
HUBUNGAN KUALITAS PELAYANAN PETUGAS PERPUSTAKAAN TERHADAP KINERJA PEGAWAI DINAS PERPUSTAKAAN DAN KEARSIPAN KABUPATEN PESAWARAN
}

\author{
Yeni Maya Sari ${ }^{(1)}$, Nur'aeni $^{(2)}$, Maria Elina ${ }^{(3)}$ \\ Fakultas Ekonomi Universitas Sang Bumi Ruwa Jurai \\ yenimaya.sari01@gmail.com,nuraeni@fe.saburai.ac.id,maria.elina@fe.saburai.ac.id
}

\begin{abstract}
Abstrak. Permasalahan dalam penelitian ini adalah Pelayanan petugas perpustakaan masih kurang optimal dan kinerja pegawai dalam menjalankan tugas pelayanan kurang maksimal Tujuan penelitian untuk mengetahui hubungan kualitas pelayanan petugas perpustakaan terhadap kinerja pegawai dinas perpustakaan dan kearsipan kabupaten Pesawaran. Metode penelitian yang digunakan dalam penelitian ini menggunakan metode penelitian deskriptif kualitatif dan kuantitatif yaitu penelirian yang bermaksud menjelaskan kedudukan variabel-variabel yang diteliti dan pengaruhnya antar satu variabel dengan variabel yang lain. Berdasarkan hasil penelitian menuujukan hubungan antara kualitas pelayanan dengan kinerja pegawai Dinas Perpustakaan dan kearsipan Kabupaten Pesawaran positif karena rhit $=0,446$ maka rhit lebih besar dari nol (0), Berarti semakin tinggi kualitas pelayanan maka semakin tinggi pula kinerja pegawai Dinas Perpustakaan dan kearsipan Kabupaten Pesawaran dan derajat keeratan hubungan antara kualitas pelayanan dan kinerja dinas perpustakaan dan kearsipan berderajat sedang karena harga rhit $=0.446$ maka rhit dalam kriteria uji terletak pada interval 0,400 - 0,600 yang berada pada taraf sedang.
\end{abstract}

Kata kunci: Kepemimpinan, Kinerja, Pegawai, Pemimpin.

\section{PENDAHULUAN}

Pegawai suatu instansi pada dasarnya merupakan satu-satunya sumber utama organisasi yang tidak dapat digantikan oleh sumber daya lainnya, sebab bagaimanapun baiknya suatu organisasi, lengkapnya fasilitas serta sarana tidak akan bermanfaat tanpa adanya pegawai yang mengatur, menggunakan dan memeliharanya. Keberhasilan instansi dalam mencapai tujuan merupakan salah satu cerminan dari organisasi yang efektif.

Pegawai negeri sebagai aparatur pemerintah dan sebagai abdi masyarakat diharapkan selalu siap menjalankan tugas dengan baik dan siap melayani masyarakat dengan baik pula. Seorang pegawai negeri dituntut untuk selalu bekerja dengan semangat yang tinggi sehingga dalam memberikan pelayanan kepada masyarakat tidak terkesan lamban, malas dan ogah-ogahan. Semangat kerja bagi pegawai negeri diperlukan untuk meningkatkan pelayanan kepada masyarakat.

Kinerja bagi suatu organisasi sangat penting karena kinerja dapat dijadikan tolak ukur suatu keberhasilan organisasi dalam melaksanakan tugasnya. Pada hakikatnya kinerja merupakan pencapaian kerja yang dicapai oleh suatu organisasi yang sesuai dengan visi, misi dan tujuan yang telah ditetapkan oleh organisasi tersebut. Kinerja menjadi sangat penting karena suatu hasil kerja dapat dikatakan tercapai apabila kebutuhan masyarakat secara luas terpenuhi.

Kebutuhan masyarakat dalam bentuk pelayanan administratif sehingga memicu untuk setiap administrator agar dapat mengimbangi kebutuhan masyarakat. agar dapat memenuhi kebutuhan masyarakat dalam bentuk administrasi setiap pegawai 
diharuskan memaksimalkan kerjanya sehingga hasil kerja (melayani masyarakat) tercapai visi, misi dan tujuan. Untuk memenuhi kebutuhan masyarakat dalam bentuk pelayanan administratif seorang administrator harus meningkatkan kualitas kerja, kedisiplinan, inisiatif, kemampuan, dan komunikasi. Dan harus mengedepankan kualitas pelayanannya sehingga masyarakat terpuaskan dengan kinerja dari para pegawai.

Pencapaian kinerja yang baik dapat diukur dari kinerja orang-orang yang bekarja dalam unit organisasi kemudian terdapat unit-unit organisasi yang dapat mendukung kinerjanya, dan akhirnya kinerja pegawai tersebut dapat berperan dibidangnya. Kualitas pelayanan ini menjadi sangat penting demi kebaikan citra suatu organisasi, oleh sebab itu organisasi harus meningkatkan kinerja para pegawainya agar kualitas pelayanannya meningkat. Dengan adanya hasil kerja (kinerja) yang terpenuhi sesuai dengan visi dan misi yaitu memberikan pelayanan yang prima maka akan meningkatkan suatu kualitas pelayanan.

Dinas Perpustakaan dan Kearsipan Kabupaten Pesawaran merupakan salah satu contoh instansi yang harus memberikan pelayanan di bidang perpustakaan dan kearspan . pelayanan ini berupa layanan perpustakaan kepada masyarakat yang membutuhkan bahan bacaan.

Perpustakaan sebagai salah satu pusat sumber informasi mempunyai akses yang strategis dalam mendukung keberhasilan pendidikan dan pembelajaran masyarakat dalam upaya mencerdaskan kehidupan bangsa dan sekaligus sebagai upaya peningkatan kualitas sumber daya manusia. Dengan adanya berbagai fasilitas yang tersedia di perpustakaan sangat mendukung dalam proses belajar masyarakat.

Dinas Perpustakaan dan Kearrsipan Kabupaten Pesawaran berupaya melakukan peningkatan terhadap kualitas pelayanan yang diberikan kepada masyarakat, peningkatan ini terjadi karena munculnya berbagai permasalahan diantaranya: pengunjung harus antri mendapatkan pelayanan petugas saat peminjaman koleksi, antrian juga terjadi di meja peminjaman dan pengembalian koleksi, pembuatan kartu anggota perpustakaan pun harus antri karena petugas pendaftaran harus menginput satu persatu data ke dalam buku peminjam, petugas pelayanan kurang ramah terhadap pengunjung serta minimnya tenaga pelayanan yang dimiliki.

Berdasarkan informasi bahwa waktu pelayanan membutuhkan durasi waktu yang lama, perpustakaan tidak memiliki standar yang pasti dalam menentukan lamanya waktu pelayanan yang diberikan untuk beberapa jenis layanan tersebut. Permasalahan-permasalahan tersebut mengidikasikan kinerja petugas pelayanan perpustakaan kurang optimal dalam memberikan layanan. Untuk mengkaji pengaruh pelayanan terhadap kinerja pegawai penulis tertarik untuk melakukan penelitian dengan judul: "Hubungan Kualitas Pelayanan Petugas Perpustakaan terhadap Kinerja Pegawai Dinas Perpustakaan dan Kearsipan Kabupaten Pesawaran".

\section{KAJIAN TEORI}

\section{Pengertian Pelayanan}

Pelayanan pada dasarnya dapat diartikan sebagai aktivitas seseorang, sekelompok orang atau organisasi langsung maupun tidak langsung untuk memenuhi kebutuhan. Menurut Sampara yang dikutip oleh Iwan Satibi dalam buku Manajemen Publik (2012) yaitu: kegiatan atau urutan kegiatan yang terjadi dalam interaksi langsung antara seseorang dengan orang lain secara fisik dan menyediakan kepuasan pelanggan. Adapun definisi lain 
menurut Moenir yang dikutip oleh Iwan Satibi dalam buku Manajemen Publik (2012) sebagai berikut pelayanan adalah sebagai proses pemenuhan kebutuhan melalui aktivitas orang lain secara langsung.

Definisi tersebut mencerminkan bahwa pelayanan mengandung sejumlah proses aktivitas yang diajukan untuk memenuhi kebutuhan pihak lain. Dengan perkataan lain, ada pihak-pihak yang memberikan layanan dan ada pihak yang dilayani sesuai dengan kebutuhannya.

Selanjutnya pengertian pelayanan publik menurut Sinambela yang dikutip oleh Iwan Satibi (2012), yaitu: Pelayanan publik adalah setiap kegiatan yang dilakukan oleh pemerintah terhadap sejumlah orang yang memiliki setiap kegiatan yang menguntungkan dalam suatu kumpulan atau kesatuan, dan menawarkan kepuasan meskipun hasilnya tidak terikat.

Pengertian Pelaynan Publik menurut Kurniawan yang dikutip oleh Iwan Satibi dalam buku Manajemen Publik (2012), adalah : Pelayanan publik adalah pemberian pelayanan keperluan orang lain atau masyarakat yang mempunyai kepentingan pada organisasi itu sesuai dengan prosedur dan peraturan yang telah ditetapkan.

\section{Indikator Kualitas Pelayanan}

Pada dasarnya, kualitas pelayanan berfokus keapada upaya pemenuhan kebutuhan dan keinginan pelanggan serta ketepatan penyampaiannya untuk mengimbangi harapan pelanggan. Dengan kata lain, terdapat faktor utama yang mempengaruhi kualitas pelayanan, yaitu jasa yang diharapkan dan jasa yang dipersepsikan. Untuk lebih mendalami tentang pengertian Kualitas Pelayanan dengan berbagai hal pokok menurut Tjiptono (2011), menemukan bahwa sepuluh dimensi yang ada dapat dirangkum menjadi lima dimensi pokok, yaitu :

1. Bukti langsung (tangible), adalah bukti konkret kemampuan suatu organisasi untuk menampilkan yang terbaik bagi stakeholder (pemangku kebutuhan). Baik dari sisi fisik tampilan bangunan, fasilitas, perlengkapan teknologi pendukung, hingga penampilan pegawai.

2. Keandalan (reliability), adalah kemampuan organisasi untuk memberikan pelayanan yang sesuai dengan harapan stakeholder (pemangku kebutuhan) terkait kecepatan, ketepatan waktu, tidak ada kesalahan, sikap simpatik, dan lain sebagainya.

3. Daya tangkap (responsiveness), yaitu memberikan pelayanan yang cepat atau responsif serta diiringi dengan cara penyampaian yang jelas dan mudah dimengerti.

4. Jaminan (assurance), yaitu jaminan dan kepastian yang diperoleh dari sikap sopan santun pegawai, komunikasi yang baik, dan pengetahuan yang dimiliki, sehingga mampu menumbuhkan rasa percaya stakeholder (pemangku kebutuhan).

5. Empati (empathy), adalah memberikan perhatian yang tulus dan bersifat pribadi kepada stakeholder (pemangku kebutuhan), hal ini dilakukan untuk mengetahui keinginan stakeholder (pemangku kebutuhan) secara akurat dan spesifik.

\section{Pengertian Kinerja}

Kinerja adalah hasil yang dicapai dari yang telah dilakukan dan dikerjakan oleh seseorang dalam melaksanakan kerja atau tugas. Kinerja merupakan prestasi kerja 
atau performance, yaitu hasil kerja selama periode tertentu dibanding dengan berbagai kemungkinan. Kinerja Pegawai secara etimologi, kinerja berasal dari kata performance. Performance berasal dari kata to perform yang mempunyai beberapa masukan (entries), yakni (1) melakukan, (2) memenuhi atau menjalankan suatu, (3) melaksanakan suatu tanggung jawab, (4) melakukan sesuatu yang diharapkan oleh seseorang. Dalam hal ini kinerja bisa dikatakan hasil kerja secara kualitas dan kuantitas yang dicapai oleh seseorang pegawai dalam melaksanakan tugasnya sesuai dengan tanggung jawab yang diberikan kepadanya.

Untuk lebih memahami apa yang dimaksud dengan Kinerja peneliti mengemukakan pengertian kinerja menurut Mahmudi yang di kutip oleh Iwan Satibi dalam buku Manajemen Publik (2012) mengemukakan bahwa Kinerja yaitu: Kesuksesan seseorang (pegawai) dalam melaksanakan suatu pekerjaan.

Pengertian kinerja menurut Lembaga Administrasi Negara Republik Indonesia (LAN-RI) yang dikutip oleh Iwan Satibi dalam bukunya Manajemen Publik (2012) adalah sebagai berikut: Kinerja adalah gambaran umum mengenai tingkat pencapaian pelaksanaan suatu kegiatan, program, kebijaksanaan dalam mewujudkan sasaran, tujuan, misi, dan visi organisasi.

\section{Faktor-faktor yang mempengaruhi Pencapaian Kinerja}

Faktor-faktor yang berpengaruh langsung terhadap tingkat pencapaian Kinerja menurut Ruky yang dikutip oleh Iwan Satibi dalam buku Manajemen Publik (2012), mengemukakan faktor-faktor mempengaruhi pencapaian kinerja sebagai berikut :

a. Teknologi yang meliputi peralatan kerja dan metode kerja yang digunakan untuk menghasilkan produk atau jasa yang dihasilkan oleh organisasi.

b. Kualitas input atau material yang digunakan oleh organisasi.

c. Kualitas lingkungan fisik yang meliputi keselamatan kerja, penataan ruangan, dan kebersihan.

d. Budaya organisasi sebagai pola tingkah laku dan pola kerja yang ada dalam organisasi yang bersangkutan.

e. Kepemimpinan sebagai upaya untuk mengendalikan anggota organisasi agar bekerja sesuai dengan standar dan tujuan organisasi.

f. Pengelolaan sumber daya manusia yang meliputi aspek kompensasi, imbalan, promosi dll.

\section{METODE PENELITIAN}

\section{Objek Penelitian}

Objek penelitian adalah Kualitas Pelayanan Petugas Perpustakaan terhadap Kinerja Pegawai Dinas Perpustakaan dan Kearsipan Kabupaten Pesawaran. Dinas Perpustakaan dan Kearsipan Kabupaten Pesawaran beralamat di Jalan Makarti Desa Bagelan IV Gedongtataan. Penelitian dilaksanakan pada bulan April 2018 sampai Juli 2018.

\section{Metode dan Teknik Pengumpulan Data}

Metode pengumpulan data yang dimaksud pada penelitian ini adalah menggunakan data pribadi subjek dan alat pengukuran atau instrumen.

Dalam penelitian ini jenis data yang diperlakukan adalah :

a. Data Primer

Data primer merupakan data dasar yang akan diperoleh langsung tanpa perantara orang atau lembaga lain sebagai pihak ketiga. Data primer ini diperoleh dengan wawancara melalui responden dengan menggunakan daftar pertanyaan. 
b. Data Sekunder

Data skunder merupakan data yang diperoleh melalui orang lain yang berhubungan dengan permasalahan yang dipecahkan. Data sekunder ini diperoleh melalui cara studi dokumenter yaitu mengumpulkan dan mempelajari brosurbrosur serta dokumen organisasi.

\section{Dalam penelitian ini, penulis menggunakan berbagai metode pengumpulan data yang akan diuraikan sebagai berikut: \\ 1. Observasi \\ 2. Wawancara \\ 3. Kuesioner \\ 4. Studi Kepustakaan dan Dokumentasi}

\section{Sampel dan Populasi}

Untuk menentukan populasi dan sampel Arikunto (2012) menyatakan ukuran minimum sampel untuk keperluan penelitian ini lebih dari 100 orang diambil sebanyak $10 \%$ dari jumlah keseluruhan populasi.

Berdasarkan pernyataan tersebut maka penulis menjadikan keseluruhan pegawai sebagai sampel, dikarenakan jumlah Pegawai Kantor Arsip dan Perpustakaan Kabupaten Pesawaran sebanyak 26 pegawai maka penulis mengambil seluruh pegawai untuk dijadikan sampel sebanyak 26 pegawai.

\section{Metode Analisis Data}

Analisis kualitatif adalah analisis yang menggambarkan secara rinci, dengan interpretasi terhadap data yang diperoleh melalui pendekatan teoritis. Dalam hal ini adalah untuk menyederhanakan data ke dalam bentuk yang lebih mudah dibaca dan diinterpretasikan melalui pendekatan teori, kemudian dideskripsikan atau dijelaskan.

Untuk mengukur keeratan hubungan antara variabel Pengawasan (X) dengan variabel Motivasi (Y) digunakan koefisien korelasi, dengan menggunakan rumus Korelasi Product Momen sebagai berikut :

$$
r_{x y}=\frac{n \sum x y-\left(\sum x\right)\left(\sum y\right)}{\sqrt{\left[n \sum x^{2}-\left(\sum x\right)^{2}\right]\left[n \sum y^{2}-\left(\sum y\right)^{2}\right]}}
$$

$r$ xy $=$ koefisien korelasi $\mathrm{x}$ dan $\mathrm{y}$

$n \quad=$ jumlah sampel yang akan diuji

$x \quad=$ jumlah skor variabel

$y \quad=$ jumlah skor dari seluruh variabel

Untuk mengetahui besarnya pengaruh, penghitungan koefisien korelasi tersebut kemudian dilanjutkan dengan Rumus Koefisien Determinasi atau Koefisien Penentu (KP):

$$
K P=(r)^{2} x 100 \%
$$

Untuk menguji secara hipotesis secara parsial digunakan Uji t dengan rumus :

$$
t_{\text {hitung }}=\frac{r \sqrt{N-2}}{\sqrt{1-r^{2}}}
$$

Keterangan:

$$
\begin{array}{ll}
\mathrm{t}_{\text {hitung }} & =\text { Nilai } \mathrm{t} \\
\mathrm{r} & =\text { Koefisien Korelasi } \\
\mathrm{N} & =\text { Jumlah responden }
\end{array}
$$

Kriteria untuk Uji $\mathrm{t}$ adalah sebagai berikut :

a) Jika $t_{\text {hitung }}>t_{\text {tabel }}$ maka Ha diterima dan Ho ditolak.

b) Jika $\mathrm{t}_{\text {hitung }} \leq \mathrm{t}_{\text {tabel }}$ maka Ha ditolak dan Ho diterima.

\section{HASIL DAN PEMBAHASAN}

\section{Analisis Kualitatif}

Berdasarkan hasil angket tentang kualitas pelayanan diperoleh hasil sebagai berikut : Sebanyak 12 responden (45\%) menjawab sangat setuju, 10 responden 
(40\%) menjawab setuju dan sisanya sebanyak 4 responden (15\%) kurang setuju. Berdasarkan hasil angket tentang kinerja diperoleh hasil sebagai berikut : rata-rata Sebanyak 22 responden (84\%) menjawab sangat setuju dan setuju, dan sisanya sebanyak 4 responden (16\%) menjawab kurang setuju dengan kinerja yang dimiliki pegawai.

\section{Uji Validitas dan Reliabilitas}

Uji validitas dilakukan dengan membandingkan nilai $r$ hitung (untuk setiap butir pertanyaan dapat dilihat pada kolom corrected item-total correlations), dengan $r$ tabel dengan mencari degree of freedom $(d f)=\mathrm{N}-\mathrm{k}$, dalam hal ini $\mathrm{N}$ adalah jumlah sampel, dan $\mathrm{k}$ adalah jumlah variabel independent penelitian. Jika $r$ hitung $>r$ tabel, dan bernilai positif, maka pernyataan (indikator) tersebut dikatakan valid.

Uji reliabilitas merupakan alat untuk mengukur suatu kuesioner yang merupakan indikator dari variabel atau konstruk. Suatu kuesioner dikatakan reliabel atau handal jika jawaban seseorang terhadap pernyataan adalah konsisten atau stabil dari waktu ke waktu (Ghozali, 2005).

\section{Analisis Kuantitatif}

Dari perhitungan atau rhit $=0,446$ maka rhit lebih besar dari nol (0), sehingga ada hubungan positif antara kualitas pelayanan dengan kinerja pegawai. Berarti semakin tinggi nilai angket kualitas pelayanan maka semakin tinggi pula kinerja pegawai Dinas Perpustakaan dan Kearsipan Kabupaten pesawaran. Derajat keeratan hubungan antara kualitas pelayanan dan kinerja dinas perpustakaan dan kearsipan berderajat sedang karena harga rhit $=0.446$ maka rhit dalam kriteria uji terletak pada interval 0,400-0,600 yang berada pada taraf sedang.

\section{KESIMPULAN DAN SARAN}

\section{Kesimpulan}

Berdasarkan hasil penelitian dan pembahasan dapat diambil simpulan sebagai berikut Hubungan antara kualitas pelayanan dengan kinerja pegawai Dinas Perpustakaan dan kearsipan Kabupaten Pesawaran positif karena $r_{\text {hit }}=$ 0,446 maka rhit lebih besar dari nol (0), Berarti semakin tinggi kualitas pelayanan maka semakin tinggi pula kinerja pegawai Dinas Perpustakaan dan kearsipan Kabupaten Pesawaran.

\section{Saran}

Saran yang dapat diberikan pada penelitian ini adalah sebagai berikut :

1. Sebaiknya pimpinan memberikan panduan dan arahan kepada pegawainya agar dapat bekerja lebih baik lagi.

2. Sebaiknya pimpinan melakukan pengawasan pada pegawainya agar dapat bekerja sesuai dengan peraturan perusahaan dan tidak menyalahgunakan wewenangnya. Serta melakukan evaluasi hasil kinerja pegawainya yang telah dicapai.

\section{DAFTAR PUSTAKA}

Algifari. 2003. Statistika Induktif untuk Ekonmi dan Bisnis. Yogyakarta: AM YKPN.

Arikunto, Suharsimi. 2010, Prosedur Penelitian Suatu Pendekatan Praktis. Jakarta : P.T Rineka Cipta.

Ghozali, Imam. 2005. Aplikasi Analisis Multivariate Dengan Program SPSS. Semarang: BPFE Undip. 
Hasibuan, Malayu S.P. 2006. Manajemen. Jakarta: Bumi Aksara.

Priyatno, Dwi. 2008. Mandiri Belajar SPSS. Yogyakarta: MediaKom.

Satibi, Iwan. 2012, Manajemen Publik dalam perspektif teoritik dan empiric. Bandung: Unpas Press.

Sedermayanti. 2009. Sumber Daya Manusia dan Produktivitas Kerja. Bandung: Mandar Maju.

Sugiono. 2007. Metode Penelitian Administrasi. Bandung: Alfabeta.

. 2014. Metode Penelitian Administrasi. Bandung: Alfabeta.

Tjiptono, Fandy. 2006. Manajemen Jasa. Yogyakarta: Andi Offset.

2007, Strategi Pemasaran, Edisi Pertama. Yogyakarta: Andi Ofset. 